\title{
COMMUNITY TRENDS TO CHOOSE THE SHARIA ECONOMIC SETTLEMENT AGREEMENT
}

\author{
Rabith Madah Khulaili Harsya \\ Doctoral Program in Law Science, Faculty of Law, Sebelas Maret University \\ ra_rasya@yahoo.com
}

\begin{abstract}
The tendency of people to choose the Sharia Economic Dispute Settlement Institution. The facts of the lack of sharia economic case submitted and decided by litigation and non-litigation institutions are the background of the research. This research is a kind of explorative research that uses qualitative approach to mengunggkap legal facts in the context of sharia economy. Data in the form of questionnaires / questionnaires processed only to describe the percentage percentage of the economic tendency of sharia community to choose dispute settlement institutions. This description is a preliminary data that lead researchers to explore the points of question needed in the interview between the results of quantitative data processing with the facts on the ground shows that people choose various options in solving the dispute sharia economy.
\end{abstract}

Keywords: sharia economic dispute, solution, litigation, non-litigation

\section{Introduction}

The mandate of Law no. 3 of 2006 article 49 on the amendment of Law no. 7 of 1989 on Religious Courts ${ }^{1}$ which was last seen by Law no. 50 of 2009 gives direction on the extension of the absolute (jurisdiction) competence of religious courts to resolve the dispute of sharia economy. ${ }^{2}$ However In 2008 along with the birth of Law no. 21/2008 concerning Sharia Banking, ${ }^{3}$ especially in the settlement of sharia banking disputes is no longer absolute to the jurisdiction of religious court this is because article 55 (1) of Law no. 21 Year 2008 stipulates the settlement of sharia banking disputes conducted by courts within the religious court; ${ }^{4}$ Paragraph (2), "In the event that the parties have agreed to a dispute settlement other than as meant in paragraph (1), dispute settlement shall be conducted in accordance with the contents of the

\footnotetext{
${ }^{1}$ Article 49 of Law no. 3 of 2006 explains that the religious courts have the duty and authority to examine, decide and settle matters at the first level between Muslim people in the field of marriage, inheritance, will, grant, wakaf, zakat, infaq, shadaqah, sharia economy. Referred to as syariah economics is deeds or business activities conducted according to sharia principles, including sharia banks, syariah micro finance institutions, sharia insurance, sharia mutual funds, syariah bonds and medium-term securities syariah, sharia securities, sharia financing, pawnshops Shari'a, pension funds for sharia financial institutions, and sharia business.

${ }^{2}$ This law is motivated by Law No. 4 of 2004 on Judicial Power as an organic law on article 24 of the 1945 PostAmendment Constitution with a one-stop system

${ }^{3}$ The issuance of Law Number 21 Year 2008 concerning Sharia Banking does not necessarily mean that Law Number 3 Year 2006 is no longer valid because in terms of legal principle here it can not be applied lex posteuri lex priori principle (past law is not applicable due to the existence of The new law). Law Number 21 Year 2008 and Law Number 3 Year 2006 have different legal legislation. Law Number 21 Year 2008 is about Sharia Banking while Law Number 3 Year 2006 concerning Religious Courts. Therefore, based on legal theory, Law no. 21 of 2008 can not rule out the Law no. 3 of 2006.

${ }^{4}$ Cik Hasan Bisri, Peradilan Agama Di Indonesia, (Jakarta: Raja Grapindo Persada, 1996), p. 23-24 and 33.
} 
contract. Furthermore, in the explanation of Article 55 Paragraph (2) of sharia banking law, it is mentioned that the meaning of dispute settlement is done in accordance with the contents of the contract is the following efforts: (1) Deliberation; (2) banking mediation; (3) Through the National Sharia Arbitration Board (BASYARNAS) or other arbitration institution; And / or (4) Through the courts within the general judicial environment. ${ }^{5}$

The provision of Article 55 paragraph (2) along with its explanation shows that there has been a reduction in the competence of religious court in the field of Islamic banking which from the explanation of Article 55 Paragraph (2) of Law no. 21 of 2008, it turns out that the general court is given the competence in the settlement of syariah economic case in the field of sharia banking which the parties are allowed to choose general court as the choice of forum in resolving the banking dispute so that it has implications to reduce the authority of religious court in solving the banking dispute which some experts The opinion of the choice of forum is an inconsistency of legislators in formulating the rule of law. ${ }^{6}$

Article 49 of Law number 3 year 2006 states that "the Religious Courts shall have the duty and authority to examine, decide upon and settle matters in the first instance between the persons of the religion of marriage, inheritance, will, grant, wakaf, zakat, infaq, shadaqah; And sharia economy ". Later in the elucidation of Article 49 it is further elaborated that the meaning "between the persons of Islam" includes any person or legal entity who voluntarily submits voluntarily to Islamic law on matters under the jurisdiction of the Religious Courts in accordance with the provisions of this Article.

Departing from this provision the subject of $\mathrm{law}^{7}$ that can litigate in the environment of Religious Courts are: First, people who are Muslims. Second, people who are non-Muslim but by themselves submit themselves voluntarily to Islamic Law. Third, the Legal Entity conducting business based on Islamic Law.

Thus the subject of non-Islamic law is possible as a party in the Shariah economic case in Religious Courts including the Legal Entity. The important principle newly enacted in this provision is the principle of submission. Submission to Islamic Law can be done either because the desire in question requires or because the law itself desires so. If there is a review of the

\footnotetext{
${ }^{5}$ Ahmad Djauhari, Arbitrase Syari'ah di Indonesia, (Jakarta: BASYARNAS, 2006), p. 25.

${ }^{6}$ Cholidul Azhar, "Aspek Hukum Bank Syariah dalam Kaitannya dengan Kompetensi Absolut Pengadilan Agama", http://badilag.mahkamahagung.go.id/artikel/publikasi/artikel/aspek-hukum-bank-syariah-dalam-kaitannya-dengankompetensi-absolut-pengadilan-agama-oleh-cholidul-azhar-sh-mhum-139, Accessed on March 12, 2017.

7 The legal subject referred to herein is anything which by law can have rights and obligations including the Legal Entity. Juridical person is a person (Persoon) which in law has subjective rights and jurisdiction. While the Legal Entity is a body that can have property, rights and duties as individuals. Further see in Hairuman Pasaribu and Suhrawardi K Lubis, Hukum Perjanjian dalam Islam, (Jakarta : Sinar Grafika, 1996), p. 14.
} 
above explanatory content of the Article, there is the word "voluntary" whereas the preceding word "by itself" so that what is meant by submission in the Elucidation of the Article is not voluntary submission but indeed the law itself requires it. So that the Sharia economic dispute involving the subject of non-Islamic law then concerned should be subject to Islamic Law ${ }^{8}$ because the law requires by itself subject to Islamic Law.

This provision has changed the old paradigm that the subject of the law is limited to Muslims only. This is mainly in response to legal developments and legal needs of the community and accommodates the fact that many of the Sharia economic actors are not only Muslims but also non-Muslims.

The problem of dualism of banking dispute settlement finally prompted one of the customers of Bank Muamalat Indonesia limited liability company is Dadang Ahmad to submit a petition for judicial review of sharia banking law, especially in article 55 paragraph (2) and (3) that is through case number 93 / PUU-X / 2012 regarding testing of Law Number 21 of 2008 concerning banking Sharia against the Constitution of the Republic of Indonesia.

The final product of the petition for judicial review filed by Dadang Ahmad is the Decision of the Constitutional Court Number 93 / PUU-X / 2012 which in its decree states to grant the Petitioners' petition in part, namely: Article 55 paragraph (2) of Law no. 21 of 2008 concerning sharia banking (State Gazette of the Republic of Indonesia 2008 Number 94, supplement to State Gazette of the Republic of Indonesia Number 4867) has no binding legal force. With the issuance of the decision of the Constitutional Court Number 93 / PUU-X / 2012, the sharia economic dispute in litigation becomes the absolute authority of religious court.

Especially in DKI Jakarta, the settlement of disputes in litigation can be traced from the report of the case received and disconnected volumes of sharia economic dispute cases accepted and resolved in the religious court of High Court of Religion Jakarta region are as follows: ${ }^{9}$

\footnotetext{
${ }^{8}$ Islamic law is a collection of efforts of Islamic jurists to apply Islamic shari'ah or laws that are in accordance with human needs and fiqh at once, which lies behind the law set by syarak, some human goodness in the world and the hereafter. Abdul Aziz Dahlan, ed., Ensiklopedi Hukum Islam, Volume IV, (New York: Ichitiar Baru van Hoeve, 1996), p. 1108.

${ }^{9}$ Processed from reports on cases received and terminated throughout the Jakarta High Court of Religion, accessed from http://pa-jakartaselatan.go.id April 15, 2015.
} 
List of number of sharia economic case in High Court of Religion (PTA) DKI Jakarta

\begin{tabular}{|c|c|c|c|c|c|c|}
\hline Number & Satker & Year & $\begin{array}{c}\text { Accepted } \\
\text { case }\end{array}$ & $\begin{array}{c}\text { Revoked } \\
\text { case }\end{array}$ & Cut down & $\begin{array}{c}\text { Unassigned } \\
\text { case }\end{array}$ \\
\hline 1 & $\begin{array}{l}\text { South } \\
\text { Jakarta } \\
\text { Religious } \\
\text { Court }\end{array}$ & $\begin{array}{c}2009 \text { to } \\
2016\end{array}$ & 9 & 2 & 3 & 4 \\
\hline 2 & $\begin{array}{l}\text { East Jakarta } \\
\text { Religious } \\
\text { Court }\end{array}$ & $\begin{array}{c}2009 \text { to } \\
2016\end{array}$ & 2 & 0 & 1 & 1 \\
\hline 3 & $\begin{array}{l}\text { Central } \\
\text { Jakarta } \\
\text { Religious } \\
\text { Court }\end{array}$ & $\begin{array}{c}2009 \text { to } \\
2016\end{array}$ & 6 & 2 & 3 & 1 \\
\hline 4 & $\begin{array}{l}\text { West } \\
\text { Jakarta } \\
\text { Religious } \\
\text { Court }\end{array}$ & $\begin{array}{c}2009 \text { to } \\
2016\end{array}$ & 9 & 2 & 3 & 4 \\
\hline 5 & $\begin{array}{l}\text { North } \\
\text { Jakarta } \\
\text { Religious } \\
\text { Court }\end{array}$ & $\begin{array}{c}2009 \text { to } \\
2016\end{array}$ & 3 & 0 & 3 & 0 \\
\hline
\end{tabular}

Based on the above data found religious judiciary in the Jakarta High Court of religion (PTA) who has never decided on Islamic economic cases such as the East Jakarta District Court. However, precisely on Wednesday, October 12, 2016 East Jakarta Religious Court executed Sita Eksekusi in the case of Sharia Economics for the first time since the enactment of the authority of religious court in handling the sharia economic dispute as regulated in Article 49 of Law Number 3 Year 2006. ${ }^{10}$ Implementation carried out based on Execution of the Application dated July 3, 2016 and has been registered in the Execution List Number 0001 / Pdt.E / 2016 / PAJT in the case of a limited liability company by Bank Muamalat Indonesia as "Execution Applicant" to the limited company Virgo Sari with a decision whereby both parties are punished to fulfill The contents of the Line Facility Agreement Agreement for Mudharabah Financing. ${ }^{11}$

The North Jakarta Religious Court as mentioned above has resolved 2 issues of sharia economic dispute. In addition, the North Jakarta Religious Court has received a letter No. W9A1/866/HK.05/II/2015 regarding the request for assistance in the execution seizure of the

\footnotetext{
${ }^{10}$ Faturrahman Djamil, Penyelesaian Pembiayaan Bermasalah di Bank Syariah, (Jakarta: Sinar Grafika, 2014), p. 146.

${ }^{11}$ East Jakarta Religious Court Performs Sita Execution on Sharia Economic Case, accessed from http://www.pajakartatimur.go.id.
} 
execution of mortgages ${ }^{12}$ and the sale by auction. The case is registered with Number 03/Eks/2014/PAJ ${ }^{13}$ dated 12 February 2015 in which the execution applicant is Limited liability company Bank Muamalat Indonesia.Tbk, having his address at Arthaloka Building, jln Jenderal Sudirman Kav.2, Central Jakarta, the requested execution, Limited company Tanjung Buton Makmur sejahtera, Having his address at Daya Mas Building, Kisamaun road number 169 Rt.03 / 06, Village Sukasari Tangerang. The object is a ship called KM. Tanjung Buton Makmur sejahtera The title of GT, 5205No 286 / ba. Currently leaning around the port of Tanjung Periuk, North Jakarta. $^{14}$

While the settlement of disputes by non-litigation can be traced to the National Syariah Arbitration Board (BASYARNAS) domiciled in Jakarta. From its inception to 2016, the volume of cases that have been completed by BASYARNAS amounted to 23 cases with details; 1 case is a syari'a hospitality matter, 1 case is the remaining syari'ah case (21 cases) is a case of syri'ah banking and 2 of the 23 cases are underway meaning not yet decided by arbitrator or arbitral assembly at the time of done by Researchers. ${ }^{15}$

\section{Method}

This study uses an empirical juridical method. In empirical legal research, the social sciences are used to analyze and provide answers to make effective the entire legal institutional structure. This study studies and examines the interrelationships between law and other social institutions.

This study uses purposive sampling technique. The technique is sampling aims to be done by taking the subject based on a specific goal. This technique is usually chosen for reasons of limited time, effort and cost, so it cannot take a large and far-off sample.

\footnotetext{
${ }^{12}$ Contracts or contracts are legally binding on both parties between the debtor and the creditor. If either party performs a wan of achievement or promises of such contract, then according to the contract can be executed the execution of the mortgage. The mortgage certificate has the same executorial power as the court decision which has permanent law, and if the debtor has an appointment injury, then based on the executorial title contained in the mortgage certificate, the holder of the mortgage enters the execution of the mortgage certificate to the head of the religious court / sharia court authorized. See Mekkadilaga, Media Komunikasi Dan Konsultasi Administrator Peradilan Agama, Issue IV, Year 2015, p. 15.

${ }^{13}$ The request for execution to the Central Jakarta religious court in this case Central Jakarta Religious Court has conducted aanmaning three times, namely December 30, 2014, January 20, 2015, and January 29, 2015. At the time of aanmaning the three requested parties justify the obligation on the amount of debt to be paid And the attorney's attorney declares that the execution of the mortgage rights (gross deed) is returned to the legal procedure as the applicant's petition for execution.

${ }^{14}$ The North Jakarta Religious Court seeks execution of mortgage rights between Bank Muamalat and Tanjung Buton Limited Liability Company prosperous in Mekkadilaga, Media Komunikasi Dan Konsultasi Administrator Peradilan Agama, Issue IV, Year 2015, p. 15.

15 Interview with Euis Nurhasanah on May 3, 2016.
} 


\section{Result and Discussion}

This theory was pioneered by German scholar Friedrich Carl von Savigny (1779-1861). This theory is embraced in several countries such as the Dutch adopted by Opzomer, Diephuis, Land and Houwing and Langemeyer. ${ }^{16}$ The theory of fiction explains that legal entities are only legal fictions where the arrangement is done by the state. ${ }^{17}$ The legal entity is only a shadow and is considered only state-made. Actually there is no legal entity, only people revive his shadow as a legal subject that can perform legal acts like humans. ${ }^{18}$ Legal fiction is a principle that everyone considers law (presumptio iures de iure). In a legal fiction, anyone without exception is considered to know the law. ${ }^{19}$ It's a big mistake if someone does not know the law (ignorante legs est lata culpa). In Latin also known as adagium ignorantia jurist non excusat means ignorance of the law can not be forgiven. One can not escape from the law by arguing whether or not to know the existence of certain laws and regulations. ${ }^{20}$

In addition, the purpose of justice of the law which is the hope of the existence of a rule, should be packed in a mechanism that supports the essence of justice itself. The law should ensure that a legislation is not just a bunch of paper no balls, but the law must ensure that a rule can be implemented, without exception. ${ }^{21}$ Basically community participation is not the ultimate goal. The real purpose is to provide a wider space to the public in general in order to be able to give a meaningful influence on the process of government in a broad sense. ${ }^{22}$

The public ignorance of the law is unforgivable (ignorantia jurist non excusat). Legal fiction is arguably a principle that contains the justification of the state for imposing everything on its people. ${ }^{23}$ Adagium legal fiction has long been abandoned, but in fact this view is embraced the world of justice, both the Supreme Court (MA) and the Constitutional Court (MK). ${ }^{24}$ Supreme Court Decision. 645K / Sip / 1970 and Decision No. MK. 001 / PUU-V / 2007 contains the same principle that one's ignorance of the law can not be a forgiving excuse. Supreme Court

\footnotetext{
${ }^{16}$ Munir Fuady, Dinamika Teori Hukum, (Bogor: Ghalia Indonesia, 2010), p. 36.

${ }^{17}$ Houlgate Laurence D., Ignorantia Juris: A Plea For Justice, (Chicago: The University of Chicago Press, 1967), p. 32.

${ }^{18}$ Wirjono Prodjodikoro, Asas-asas Ilmu Negara dan Politik, (Bandung: PT. Eresco, 1981), p. 38.

${ }^{19}$ Ahmad Ali, Menjelajahi Kajian Empiris Terhadap Hukum, (Jakarta: Kencana, 2013), p. 61.

${ }^{20}$ Leden Marpaung, Menggapai Tertib Hukum Nasional, (Jakarta: Sinar Grafika, 1999), p. 65.

21 Agus Surono, Fiksi Hukum dalam Pembuatan Peraturan Perundang-undangan, (Jakarta: Universitas Al-Azhar Indonesia, 2013), p. 107-108.

${ }^{22}$ Soeprapto, Maria Farida Indrati, Ilmu Perundang-undangan; Dasar-dasar dan Pembentukannya, (Yogyakarta: Kanisius, 1998), p. 76.

${ }^{23}$ Yuliandri, Asas-Asas Pembentukan Peraturan Perundang-undangan yang Baik; Gagasan Pembentukan Undangundang Berkelanjutan, (Jakarta: Rajawali Press, 2010), p. 292.

${ }^{24}$ Agus Surono, Op. Cit, p. 161.
} 
Decision. $77 \mathrm{~K} / \mathrm{Kr} / 1961$ stipulates that everyone is considered to know the law after the law is enacted in the state gazette.

\subsection{The Theory of the Legal System}

The legal system is a unity consisting of elements or elements that interact with each other. The legal system is open and closed. Open legal system means the elements of the system affect the elements outside the system. While the closed legal system is the elements of the legal system that can not be influenced by elements outside the system. ${ }^{25}$

A good legal system can be seen from the work procedures and governance of all elements to enforce the law in order to create legal certainty. Each element influences and reinforces each other in carrying out its functions. The functions of the legal system are (1) as part of the social control system that regulates human behavior; (2) Means to settle dispute settlement; (3) As a social engineering function; (4) Social maintenance is a function that emphasizes the role of law as a person welfare status quo who does not want change. ${ }^{26}$

The legal system of a country greatly affects the effectiveness of law enforcement. There are three elements of the legal system as described by Lawrence M. Friedman namely: Structure of law, Substance of law and legal culture. ${ }^{27}$ Legal Structure is an institution created by a legal system authorized to make and implement the law in the form of service and law enforcement. Thus, the legal structure concerns lawmakers such as legislative and law enforcement agencies such as courts. The substance of law is the legal norms (rules and decisions) resulting from legal products. So the substance of the law includes the tools of legislation. While culture is the attitude of people to the law and the legal system itself that includes the belief in values, thoughts or ideas, attitudes, expectations, and opinions related to the law both positive and negative. So the legal culture is a living law that is adopted in society.

A good legal structure will not work well if it is not supported by good legal substance. Similarly, a good legal substance will not be perceived if not supported by a good legal structure. Furthermore, the structure and substance of a good law will not be perceived existence if not supported by the culture of good society law as well. The structure and substance of the law are the real components of the legal system. But both are just blueprints or designs and not machines that are working. These two components are like lifeless photos that are lifeless, rigid, frozen and do not show motion and reality.

\footnotetext{
${ }^{25}$ Niklas Luhmann, Social as a Social System, (New York: Oxford University Press, 2004), p. 72.

${ }^{26}$ Satjipto Rahardjo, Hukum dalam Jagad Ketertiban, (Jakarta: UKI PRESS, 2006), p. 170.

${ }^{27}$ Lawrence M. Frietman, American Law, (Ner York: WW. Norton \& company, 1984), p. 5-6.
} 
The legal system will work if there are social forces that move the law. These forces consist of elements of social values and attitudes called legal culture. Social force is an abstraction that does not directly move the legal system but needs to be transformed into formal demands to mobilize the workings of the legal system in court.

Fiedmen examines the culture of national law in contrast to the legal subcultures that have a positive or negative effect on national law. It also distinguishes internal and external legal culture. The culture of internal law is a legal culture of citizens who carry out legal duties such as police, prosecutors and judges in carrying out their duties. While the external legal culture is the legal culture of society in general. For example how the attitude and knowledge of society against the provisions of taxation, divorce and so forth.

Law is a subsystem in the system to the life of the state. As one system, the law will affect the performance of other systems in the life of the state. A country whose democratic legal system will create a democratic life in all spheres of life. The democratization of the law is determined by the legal development strategy adopted by a State. ${ }^{28}$

\subsection{Preference of Sharia Economic Society in Selecting Dispute Settlement Institution}

The tendency of Sharia Financial Institution to choose sharia economy dispute resolution institution can be seen in the following:

List of dispute resolution options for sharia economic

\begin{tabular}{clcc}
\hline Number & \multicolumn{1}{c}{ Institute } & $\begin{array}{c}\text { Number in Table } \\
\text { Frequency }\end{array}$ & Percentage (\%) \\
\hline 1 & Religious court & 72,7 & $41,6 \%$ \\
2 & District Court & 11,4 & $6,5 \%$ \\
3 & BASYARNAS & 25 & $14,3 \%$ \\
4 & Other Alternative Dispute & 23,8 & $13,6 \%$ \\
& Resolution (ADR) & & \\
& Institutions & 41,9 & $24 \%$ \\
\hline
\end{tabular}

In order to solve the sharia economic dispute, religious court is the highest choice of respondents that is equal to $41.6 \%$. Followed by an informal dispute resolution of $24 \%$, BASYARNAS of $14.3 \%$, other ADR institutions $13.6 \%$ and the district court of $6.5 \%$. The interesting thing about this exposure is the large portion of the informal dispute resolution of

\footnotetext{
${ }^{28}$ Josept Raz, The Concept of A Legal System, (New York: Clarandom Press Oxford, 1980), p. 112-113 in the book Teguh Prastyo \& Abdul Halim Barkatullah, Filsafat, Teori dan Ilmu Hukum: Pemikiran Menuju Masyarakat Berkeadilan dan Bermartabat, (Jakarta: PT. RajaGrafindo Persada, 2013), p. 314.
} 
sharia economy that is $24 \%$. Informal dispute resolution ranks second after religious court. ${ }^{29}$ After a re-examination to see exactly the extent of the tendency of Islamic financial institutions to choose sharia economic dispute resolution institutions, Baitul Mal Wattamwil (BMT) is the largest institution that uses the settlement informally. This is shown in the following table:

The choice of dispute resolution of sharia economy by BMT

\begin{tabular}{clcc}
\hline Number & \multicolumn{1}{c}{ Institute } & $\begin{array}{c}\text { Number in Table } \\
\text { Frequency }\end{array}$ & Percentage (\%) \\
\hline 1 & Religious court & 47,7 & $20,56 \%$ \\
2 & District Court & 26,3 & $11,34 \%$ \\
3 & BASYARNAS & 47,4 & $20,43 \%$ \\
4 & Other Alternative Dispute & 47,4 & $20,43 \%$ \\
& Resolution (ADR) & & \\
& Institutions & & \\
5 & Informal & 63,2 & $27,24 \%$ \\
\hline
\end{tabular}

Based on the data it can be seen that the tendency of BMT to choose institutions and ways of dispute resolution is quite diverse. Although the diversity of BMT choices is dominated by informal means of $27.24 \%$. But in reality, BMT as a microfinance institution of sharia has not reached the stage of dispute settlement to litigation and non-litigation stage such as syaria bank and Sharia insurance. In addition to platfon and the ability to provide micro financing, the use of financing funds is difficult to monitor. Therefore, BMT prefer the way of dispute the sharia economy in an informal way. ${ }^{30}$

\subsection{Factors Affecting Islamic Financial Institutions to Select Islamic Sharia Dispute Settlement Institutions}

The development of Islamic banking in Indonesia is so fast and quick, but some people still exist who believe that Islamic banks, conventional banks are using Islamic terms to lure the Muslim community. ${ }^{31}$ In Islamic banking, known as sharia governance, so that the principles of sharia could be optimized. ${ }^{32}$

\footnotetext{
${ }^{29}$ Khotibul Umam, Kembalinya Kompetensi Absolut Peradilan Agama, In Constitution Magazine, September Edition, 2013 No. 79, p. 35.

${ }^{30}$ Khotibul Umam, Penyelesaian Sengketa di Luar Pengadilan, (Yogyakarta: Pustaka Yustisia, 2010), p. 176.

${ }^{31}$ Bagya Agung Prabowo \& Jasri Bin Jamal, Concept And Application Of Akad Wakalah In Murabaha Financing In Islamic Banking (A Comparative Study Between Indonesia And Malaysia), Diponegoro Law Review, April 2017, Volume 02, Number 01, p. 1-14.

${ }^{32}$ Ro'fah Setyowati, Lastuti Abubakar, Nunung Rodliah, Sharia Governance On Islamic Banking: Spiritual Rights Perspective On Consumer Protection In Indonesia, Diponegoro Law Review, April 2017, Volume 02, Number 01, p. 227-244.
} 
The choice of Islamic financial institutions to choose institutions and ways of dispute sharia economic dispute is very diverse. ${ }^{33}$ The diversity of choices are: First, the regulatory factor. With the variety of laws and regulations governing dispute settlement institutions, there are various choices of people to choose sharia economic dispute resolution institutions even though the Decision of the Constitutional Court. 93 / PUU-X / 2012 on the annulment of the explanation of paragraph 2 of Article 55 of Law no. 21 Year 2008 has strengthened the absolute competence of religious courts in terms of dispute resolution of sharia economy. ${ }^{34}$

BTN Shariah before issuing fatwa DSN No. 83/DSN-MUI/VI/2012 on the Direct Shifting Tiered Sharia of Umrah Travel Services, selected BASYARNAS for the resolution of the sharia economic dispute. This is in accordance with the DSN No fatwa. 80/DSN-MUI/III/2011 concerning Implementation of Sharia Principles in Equity Securities Trading Mechanism in the Regular Market The Securities Exchange clearly states the settlement of its dispute through BASYARNAS. ${ }^{35}$ After the DSN fatwa issued. 83/DSN-MUI/VI/2012, the settlement of disputes through religious courts. In practice, sometimes dispute settlement is conducted through a state court. ${ }^{36}$ This is due to the willingness of the plaintiff who still believes in and believes in the district court. When a plaintiff in this case a bank customer either in the form of an individual or an institution submits a dispute over sharia economy to a state court, the sharia bank as a defendant has two possibilities, namely to apply escaping based on agreement in the contract clause that dispute resolution in religious court and fulfill the plaintiff's will because According to the analysis of the defendant is not too damning the defendant. ${ }^{37}$

The same thing happened in Bank Syariah Mandiri (BSM). Sometimes dispute settlement is done through BASYARNAS with execution executives of BASYARNAS verdicts existing through religious courts and some through state courts. ${ }^{38}$ Meanwhile Bank Muamalat Indonesia (BMI) resolved the sharia economic dispute before the issuance of Law no. 3 Year 2006 through BASYARNAS. Having applied Law no. 3 of 2006 even before the Decision of the Constitutional Court in its decision. 93/PUU-X/2012 on the annulment of the explanation of paragraph 2 of Article 55 of Law no. 21 Year 2008 on Sharia Banking, the settlement of dispute sharia Bank Muamalat Indonesia through religious court.

\footnotetext{
${ }^{33}$ Rahmadi Usman, Pilihan Penyelesaian Sengketa di Luar Pengadilan, (Bandung: PT. Citra Aditya Bakti, 2003), p. 316.

34 Hasbi, Kompetensi Peradilan Agama dalam Perkara Ekonomi Syariah, Dissertation, (Jakarta : Syarif Hidayatullah State Islamic University Graduate School, 2009), p. 231.

${ }^{35}$ Ahmad Mujahidin, Prosedur Penyelesaian Sengketa Ekonomi Syariah di Indonesia, (Bogor: Ghalia, 2010 ), p. 79.

${ }^{36}$ Diana Rahmi, "Ruang Lingkup Kewenangan Peradilan Agama Dalam Mengadili Sengketa Ekonomi Syariah", In the Sharia Journal of Law and Thought, Vol 13, No. 2 of 2013, p. 198.

${ }^{37}$ Results of interview with one of the legal officer of Bank BTN on February 20, 2017.

${ }^{38}$ Based on several examples of existing contracts in BSM.
} 
Particularly in contracts that are not in the form of contracts of banking products in banking operations that carry out intermediary functions such as procurement contracts, renovations and development, in case of dispute the settlement is BASYARNAS because such contracts are included in general civil contracts. ${ }^{39}$ At the Insurance Agency Sharia is not much different from the practice that occurs in sharia banking in terms of dispute resolution of sharia economy. Dispute settlement at Takaful Indonesia Limited Liability Company and Takaful Family Limited Company is through BASYARNAS and religious court. Other sharia insurers, in addition to the settlement of disputes through BASYARNAS and religious courts, still exist through the district court. ${ }^{40}$

After considering the practice of dispute resolution of sharia economy in sharia financial institution, researcher understand that there are two faction of practice of dispute of Sharia economic dispute, that is faction of syariah financial institution both bank and Takaful Insurance which fully obedient to Law no. 3 of 2006 and the factions of Islamic financial institutions, both banks and Islamic insurance are not fully subject to Law no. 3 of 2006 because there are still some who choose the district court to check the case of Islamic economics. ${ }^{41}$

Both factions arise due to the values, beliefs, perspectives and traditions that grow and live in the environment of every Islamic financial institution. Bank Syariah Mandiri, for example, is thick and loaded with the values held and traditions prevailing in Bank Mandiri, especially in terms of dispute resolution that has been accustomed to using the district court. Likewise with BTN Sharia as a Sharia Business Unit (UUS) from the State Savings Bank (BTN) which has also become a tradition in terms of dispute resolution through the district court. Unlike Bank Muamalat Indonesia, Takaful Indonesia Limited Company and Family Takaful who from the beginning berber its has a content of the tradition of kesyariahan quite thick. In legal studies, values, beliefs, worldviews and traditions like these are better known as legal culture terms as in Friedmen's legal system theory.

Second, the principle of freedom of contract. The variety of dispute resolution clauses in Islamic financial institutions is possible because of the principle of freedom of contract ${ }^{42}$ (party autonomy or freedom of contract) as regulated in article 1338 paragraph (1) of the Civil Code

\footnotetext{
${ }^{39}$ Based on the interview result of the researcher with one of legal officer of Bank Muamalat Indonesia on February $10,2017$.

${ }^{40}$ Based on several examples of contracts in several sharia insurance institutions.

${ }^{41}$ Warkum Sumitro, Asas-asas Perbankan Islam dan Lembaga-lembaga Terkait (BAMUI dan Takaful) di Indonesia, (Jakarta: Raja Grafindo Persada, 1997), p. 71.

${ }^{42}$ The principle of freedom of contract is a principle which gives freedom to the parties to make or not to enter into agreements, enter into agreements with any person, determine the contents of the agreement, the implementation, and the conditions and determine the form of the agreement whether written or oral. Salim, Hukum Kontrak: Teori dan Teknik Penyusunan Kontrak, (Jakarta: Sinar Grafika, 2006), p. 9.
} 
which states that all legally-made agreements act as laws for Those who make it. As a logical consequence of the imposition of the principle of freedom of contract, the parties to a contract may determine: ${ }^{43}$ (1) The choice of law in which the parties decide themselves in the contract of law applicable to the interpretation of the contract. (2) Choice of forum (choice of forum or choice of jurisdiction) that the parties determine by themselves in the contract regarding the court or forum where applicable in case of dispute among the parties in the contract. (3) The choice of domicile (ie, the respective party shall make the appointment of which the legal domicile of the parties. ${ }^{44}$

According to the researcher, the legal certainty aspired by the decision of the Constitutional Court to affirm the absolute competence of religious courts in solving the sharia economic dispute is still not fully realized because there are still parties to the dispute to settle the dispute to the district court under the pretext of the principle of freedom of contract embraced. Sudargo Gautama stated that the choice of law and choice of forum in the context of freedom of contract should not be carried out in a haphazard manner. The choice of law and choice of forum in question shall not be contradictory and contrary to applicable laws and regulations. ${ }^{45}$

Freedom of contract in paragraph 2 of article 55 of Law no. 21 of 2008 concerning sharia banking after the Decision of the Constitutional Court in the decision no. 93/PUU-X/2012 only allows the choice of the parties to choose a religious court to resolve the dispute over sharia economy by litigation or alternative despiration resolutions such as BASYARNAS as stipulated in Law no. 30 of 1999 on arbitration.

Third, the human resource factor. Human resources are commonly referred to as human resources in the context of sharia economics. In this case the legal existing in various Islamic financial institutions are very diverse background ranging from general law scholars, Islamic law in this case muamalat (economic law and sharia business) and scholars of sharia. Based on the results of interviews with one of the legal banks sharia explained that the majority of legal persons are behind the common law. The current effort is to improve the competence of legal entities in terms of Islamic law and the science of kesyariahan by means of training and certification. In addition, the recruitment pattern of legal officers has been open to receive

\footnotetext{
${ }^{43}$ Garry Goodpaster, "Tinjauan terhadap Penyelesaian Sengketa”, In Agnes Toar et al, Dasar Hukum Ekonomi 2 Abitrase Indonesia, (Jakarta: Gralia Indonesia, 1995), p. 64.

${ }^{44}$ Munir Fuady, Hukum Kontrak: Dari Sudut Pandang Hukum Bisnis, (Bandung: PT. Citra Aditya Bakti, 2003), Book 2, Print. 1st, p. 137.

${ }^{45}$ Sudargo Gautama, Hukum Perdata Internasional Indonesia, (Jakarta: Bina Cipta, 1992), Volume III, part 2, book 8, p. 170.
} 
scholars who have Islamic legal background in this muamalat (economic law and sharia business) and sharia scholars. ${ }^{46}$

Based on the results of interviews with one of the informants BTN Syariah related to the contract, not all financial institution business contracts made by the legal officers. Authentic data required in business contracts such as commercial financing, for example, require the services of notaries primarily on commercial financing as contained in BTN Sharia. Notaries in Indonesia, the majority of their competence in the field of economic law and sharia business as well as kesyariahan science is not maximal yet. In addition, shariah contracts and deed forms are also not in accordance with the regulations as well as contracts and public deeds. This condition causes the legal reasoning to be diverse in understanding freedom of contract. Their reasoning affects the choice of law in terms of dispute resolution of sharia economy as in point 2 . The Supreme Court should have issued a circular to the district court for not accepting the resolution of the sharia economic dispute in order to ensure legal certainty over the obsolut competence of the religious court.

Fourth, institutional factors. Institutions referred to here are the competencies of the institutions namely religious courts, district courts and BASYARNAS as well as the competence of judges and arbitrators. The respondent response to 3 dispute resolution institutions can be seen in the following:

\begin{tabular}{clcc}
\hline Number & \multicolumn{1}{c}{ Institute } & $\begin{array}{c}\text { Number in Table } \\
\text { Frequency }\end{array}$ & Percentage (\%) \\
\hline 1 & Religious court & 72,7 & $54,25 \%$ \\
2 & District Court & 22,7 & $16,94 \%$ \\
3 & BASYARNAS & 38,6 & $28,81 \%$ \\
\hline
\end{tabular}

While the response of the respondents to the competence of judges of religious courts and state courts and arbiters BASYARNAS in solving the dispute sharia economy can be seen in the following:

\begin{tabular}{clcc}
\hline Number & \multicolumn{1}{c}{ Institute } & $\begin{array}{c}\text { Number in Table } \\
\text { Frequency }\end{array}$ & Percentage (\%) \\
\hline 1 & $\begin{array}{l}\text { Judge of the Religious } \\
\text { court }\end{array}$ & 65,9 & $53,23 \%$ \\
2 & $\begin{array}{l}\text { Judge of the District } \\
\text { Court }\end{array}$ & 13,7 & $11,07 \%$ \\
3 & $\begin{array}{l}\text { Arbitrator of the } \\
\text { BASYARNAS }\end{array}$ & 44,2 & $35,7 \%$ \\
\hline
\end{tabular}

${ }^{46}$ Roihan A. Rasyid, Hukum Acara Peradilan Agama, (Jakarta: PT. Raja Grafindo Persada, 2002), p. 53. 
What is shown based on this data is in accordance with the expression Rifyal Ka'bah in 2010 which explains that religious judges are sufficient in deciding sharia economic case. This can be seen from the already dozens of Islamic economics cases that go to religious courts can still be resolved properly until the cassation. The issue of at least the entry cases, depending on the willingness of the contractual parties to settle the dispute through a religious court or BASYARNAS. ${ }^{47}$

Fifth, time and cost efficiency factor. Respondent's response to the efficiency of litigation time in litigation and non-litigation institutions can be seen in the following:

\begin{tabular}{clcc}
\hline Number & Institute & $\begin{array}{c}\text { Number in Table } \\
\text { Frequency }\end{array}$ & Percentage (\%) \\
\hline 1 & Religious court & 15,6 & $18,33 \%$ \\
2 & District Court & 42,2 & $49,6 \%$ \\
3 & BASYARNAS & 27,3 & $32,07 \%$ \\
\hline
\end{tabular}

While the respondent's response to the cost efficiency of litigation in litigation and nonlitigation institutions can be seen in the following table:

\begin{tabular}{clcc}
\hline Number & \multicolumn{1}{c}{ Institute } & $\begin{array}{c}\text { Number in Table } \\
\text { Frequency }\end{array}$ & Percentage (\%) \\
\hline 1 & Religious court & 17,7 & $24,5 \%$ \\
2 & District Court & 34 & $48,5 \%$ \\
3 & BASYARNAS & 20,5 & $28,4 \%$ \\
\hline
\end{tabular}

Based on the percentages presented in previous frequency tables shows that the efficiency of time and cost of litigation is not dominant compared to other factors. The researcher's analysis is similar to Mirza Karim's opinion, a lawyer at Karim Consulting, who explains that the long and short time needed for litigation and cheapness-the cost of litigation through courts and BASYARNAS is relatively clear in terms of time. The trial is longer than BASYARNAS and other ADR agencies because if the case continues to appeal and cassation. ${ }^{48}$ It could also be a short time if a first-level court decision is acceptable. Expensive and low cost of litigation are also relative. Trial in court may be cheaper if first-degree court decisions are acceptable. It should be remembered, however, that a court decision may be compared to a high court and may also be appealed to the Supreme Court and it is also possible to request a review to the Supreme Court. The longer the process is more expensive and expensive, especially if you use the services of advocates. The costs of litigation through arbitration may also be more costly because institutionally such as BASYARNAS is not a government-owned entity. But the verdict can not

\footnotetext{
47 Training of Prospective Judges Force-2 in Banten, 2007.

${ }^{48}$ Abdul Manan, Beberapa Masalah Hukum dalam Praktek Ekonomi Syariah, Paper
} 
be compared to the cassation. In addition, if the party loses beriktikad not good in the sense of arbitration verdict is not voluntarily adhered to request the determination of execution to the district court. $^{49}$

Relating to the efficiency of time and cost of litigation, specifically BMT as a sharia micro finance institution has not reached the stage of dispute settlement such as other sharia financial institutions such as banks and Takaful Insurance. In addition to the platform and ability to provide micro financing, the use of financing funds is difficult to monitor. Therefore, BMT prefer the way of dispute the sharia economy in an informal way.

\section{Conclusion}

Sharia financial institutions are very diverse to choose the way and choose sharia economic dispute resolution institutions. Some choose religious courts, BASYARNAS, other ADR agencies and even state courts. The varied choice of respondents to choose the dispute resolution institution for religious courts, BASYARNAS and other ADR institutions as well as religious courts is caused by 5 factors: regulatory factors, freedom of contracting principle, human resources, institutional and time efficiency and litigation costs.

With the diverse interpretation of legal experts and legal officers and other legal practitioners to translate Law no. 3 of 2006 which affirms the absolute competence of religious courts in terms of sharia economy and Law no. 21 of 2008 concerning Sharia Banking despite the explanation of paragraph 2 of Article 55 of Law no. 21 of 2008 concerning Sharia Banking has been canceled by the Constitutional Court with the decision No. 93/PUU-X/2012 so that still found the settlement of sharia economic dispute settled through the state court and even BASYARNAS execution is still done by the district court. Should the Supreme Court expressly through a circular to the district court not to accept dispute settlement related to business and sharia economy.

Because the problem is also a major problem in the settlement of sharia economic disputes. Therefore it is necessary to improve the competence of human resources. In addition, recruitment of candidate human resources in the field of economic law and sharia business both distributed as academics and legal practitioners are also required. The government should support and promote formal educational institutions that are concerned to study and study programs of

${ }^{49}$ Rahmat Rosyadi dan Ngatino, Arbitrase dalam Perspektif Islam dan Hukum Positif, (Bandung: PT. Citra Aditya Bakti, 2001), p. 61. 
economic law and sharia business and provide clear regulation to recruit the graduates of sharia business economics law.

\section{References}

Ali, Ahmad, (2013). Menjelajahi Kajian Empiris Terhadap Hukum, Jakarta: Kencana.

Azhar, Cholidul, (2017). “Aspek Hukum Bank Syariah dalam Kaitannya dengan Kompetensi Absolut Pengadilan Agama”, http://badilag.mahkamahagung.go.id/artikel/publikasi/artikel/aspek-hukum-bank-syariahdalam-kaitannya-dengan-kompetensi-absolut-pengadilan-agama-oleh-cholidul-azhar-shmhum-139, Accessed on March 12,.

Bisri, Cik Hasan, (1996) Peradilan Agama di Indonesia, Jakarta: Raja Grapindo Persada,.

Dahlan, Abdul Aziz, ed., (1996). Ensiklopedi Hukum Islam, Volume IV, New York: Ichitiar Baru van Hoeve,.

Djamil, Faturrahman, (2014). Penyelesaian Pembiayaan Bermasalah di Bank Syariah, Jakarta: Sinar Grafika.

Djauhari, Ahmad, (2006). Arbitrase Syari'ah di Indonesia, Jakarta: BASYARNAS,.

Frietman, Lawrence M, 1(984) American Law, New York: WW. Norton \& company.

Fuady, Munir, (2010). Dinamika Teori Hukum, Bogor: Ghalia Indonesia.

Fuady, Munir, (2003).Hukum Kontrak: Dari Sudut Pandang Hukum Bisnis, Bandung: PT. Citra Aditya Bakti.

Gautama, Sudargo, (1992). Hukum Perdata Internasional Indonesia, Jakarta: Bina Cipta, , Volume III, part 2, Book 8.

Goodpaster, Garry, (1995) "Tinjauan terhadap Penyelesaian Sengketa”, In Agnes Toar et al, Dasar Hukum Ekonomi 2 Abitrase Indonesia, Jakarta: Gralia Indonesia.

Hasbi, (2009). Kompetensi Peradilan Agama dalam Perkara Ekonomi Syariah, Dissertation, Jakarta : Syarif Hidayatullah State Islamic University Graduate School.

Kardono, A.Suiani, Hukum dan Lembaga Arbitrase di Indonesia, Jakarta: t.p, tt.

Laurence D., Houlgate, (1967). Ignorantia Juris: A Plea For Justice, (Chicago: The University of Chicago Press.

Luhmann, Niklas, (2004). Social as a Social System, New York: Oxford University Press.

Marpaung, Leden, (1999)Menggapai Tertib Hukum Nasional, Jakarta: Sinar Grafika,. 
Mekkadilaga, (2015), Media Komunikasi dan Konsultasi Administrator Peradilan Agama, Issue IV.

Mujahidin, Ahmad, (2010). Prosedur Penyelesaian Sengketa Ekonomi Syariah di Indonesia, Bogor: Ghalia,.

Pasaribu, (1996). Hairuman and Suhrawardi K Lubis, Hukum Perjanjian dalam Islam, Jakarta : Sinar Grafika.

Prabowo, Bagya Agung \& Jasri Bin Jamal, (2017) Concept And Application Of Akad Wakalah In Murabaha Financing In Islamic Banking (A Comparative Study Between Indonesia And Malaysia), Diponegoro Law Review, , Volume 02, Number 01, April, p. 1-14.

Prastyo, (2013). Teguh dan Abdul Halim Barkatullah, Filsafat, Teori dan Ilmu Hukum: Pemikiran Menuju Masyarakat Berkeadilan dan Bermartabat, Jakarta: PT. RajaGrafindo Persada.

Prodjodikoro, Wirjono, (1981). Asas-asas Ilmu Negara dan Politik, Bandung: PT. Eresco, 1981. Asas-asas Ilmu Negara dan Politik, Bandung: PT. Eresco.

Rahardjo, Satjipto, (2006). Hukum dalam Jagad Ketertiban, Jakarta: UKI PRESS,.

Rahmi, Diana, (2013). Ruang Lingkup Kewenangan Peradilan Agama Dalam Mengadili Sengketa Ekonomi Syariah, In the Sharia Journal of Law and Thought, Vol 13, No. 2.

Rasyid, Roihan A., (2002). Hukum Acara Peradilan Agama, Jakarta : PT. Raja Grafindo Persada.

Raz, Josept, (1980). The Concept of A Legal System, New York: Clarandom Press Oxford,.

Ro'fah Setyowati, Lastuti Abubakar, Nunung Rodliah, (2017). Sharia Governance On Islamic Banking: Spiritual Rights Perspective On Consumer Protection In Indonesia, Diponegoro Law Review, April 2017, Volume 02, Number 01, p. 227-244.

Rosyadi, Rahmat dan Ngatino, (2001). Arbitrase dalam Perspektif Islam dan Hukum Positif, Bandung: PT. Citra Aditya Bakti.

Salim, (2006). Hukum Kontrak: Teori dan Teknik Penyusunan Kontrak, Jakarta: Sinar Grafika,.

Sumitro, Warkum, (1997). Asas-asas Perbankan Islam dan Lembaga-lembaga Terkait (BAMUI dan Takaful) di Indonesia, Jakarta: Raja Grafindo Persada,

Surono, Agus, (2013). Fiksi Hukum dalam Pembuatan Peraturan Perundang-undangan, Jakarta: Universitas Al-Azhar Indonesia,.

Training of Prospective Judges Force-2 in Banten, 2007.

Umam, Khotibul, (2013). Kembalinya Kompetensi Absolut Peradilan Agama, In Constitution Magazine, September Edition, No. 79. 
Usman, Rahmadi, (2003). Pilihan Penyelesaian Sengketa di Luar Pengadilan, Bandung: PT. Citra Aditya Bakti,.

Yuliandri, (2010). Asas-asas Pembentukan Peraturan Perundang-undangan yang Baik; Gagasan Pembentukan Undang-undang Berkelanjutan, Jakarta: Rajawali Press,. 